\title{
Has Russia Established a New International Role?
}

Russia's Prospects as a "Sovereignty Provider"

Paul J. Saunders

Moscow's largely successful defense of the Bashar al-Assad regime in Syria, and its more recent diplomacy surrounding Turkey's efforts to establish a so-called "safe zone" on the Syrian side of their shared border, has prompted some Russian foreign policy analysts and commentators to refer to their country as a "security provider" or, more narrowly, a "sovereignty provider" in international affairs. Despite its high-profile activity in Syria, however, Russia's international security role may remain more limited than this view suggests.

As Russia's first significant military intervention outside the former Soviet region in decades, Moscow's four-year Syrian operation has appropriately attracted considerable attention. Russian military forces have demonstrated new capabilities, won substantial experience, and overcome some of the shortcomings exposed in their war in Georgia, such as in integrating air and ground combat. More important from an international affairs perspective, Moscow prevented Syria's collapse and kept its ally President Assad in power. Russia has accomplished this at a relatively low cost in lives and money while maintaining a fairly narrow definition of its role and campaign objectives.

Paul J. Saunders is a Senior Fellow in U.S. Foreign Policy at the Center for the National Interest.

This article is an abridged version of the paper written for the Valdai International Discussion Club. The original version is available at: http://valdaiclub.com/a/highlights/has-russiaestablished-a-new-international-role/?sphrase_id=1392213

DOI: 10.31278/1810-6374-2019-17-4-203-206 
It is understandable that a success like this would stimulate pride within a foreign policy and national security elite long frustrated by the gap between the Soviet Union's international standing and that of Russia today. Such sentiments would be especially attractive at a time when Russian observers see American power as declining. Nevertheless, Russia's experts-and leaders-would do well to maintain a sense of perspective about what Moscow has accomplished and why and how its Syria policy has generally worked so far.

Consider some of the key elements of the conflict in Syria that have thus far functioned to Russia's advantage. First, while Syria is outside the former Soviet region, it is not too far from Russia and, because it is a littoral Mediterranean country, it is easily accessible for the Russian military. The combination of these two factors means that Russia has been able to deploy and resupply its forces in a timely manner by sea rather than by air, which would have imposed greater stress on Russian capabilities.

Second, Russia has not faced a sophisticated or modern military force opponents in combat with Syria's rebel forces or Islamic State militants. This has permitted the Russian military to use helicopters without undue risk from surface-to-air missiles, for example, and has otherwise limited the dangers to Russian personnel and equipment.

Third, Moscow had an essential ally in Iran, which supplied its regular military forces as well as facilitated the operations of thousands of Lebanese Hezbollah fighters, who provided critical support to Syria's ground forces. This obviated the use of additional Russian ground troops, reduced casualties, and avoided additional strain on Russia's resupply mission.

Fourth, Russia benefited from an environment in which its main competitor-the United States-voluntarily limited its own involvement in Syria. This does not mean simply that former President Barack Obama and current President Donald Trump have rejected significant U.S. military operations in Syria; it has meant much more than that. Washington had long taken the lead in air strikes against the Islamic State, which in turn allowed Russia to concentrate its fire against Syrian opposition troops. Washington did not provide advanced weapons to Syria's opposition and has been working to deny them to ISIS too. Washington also worked to contain the conflict and 
to constrain regional allies and partners who might otherwise have supported the forces Russia has been fighting. Indeed, excepting Iran, regional players' participation in Syria's civil war may well have peaked before Russia launched its intervention.

Finally, as Russian officials like to point out, the Syrian government requested Russia's help and invited the Russian military into their country. On top of this, Russia already had a small naval facility in Syria and, with Syrian help, was able rapidly to establish an important air base. Where else will Russia receive a similar welcome?

With all of this in mind, Russia's leaders might ask themselves how likely it is that Moscow will be able to repeat its Syrian operation in another location away from their country's borders. But they probably do not need to ask that, because it seems fairly obvious that Russia cannot count on similarly favorable military conditions elsewhere. That makes the idea of Russia as a global "security provider" unsustainable.

Setting aside the military factors, there are also some important reasons to be skeptical about how international political conditions will influence Russia's global role. The biggest question is the United States, which has largely abstained from meaningful involvement in the Syria conflict, leading some to expect an enduring reduction in America's international engagement. That would be a mistake.

Long-term U.S. combat operations in Iraq and (to a lesser extent) Afghanistan have indisputably fueled public frustration with what President Trump calls "endless wars." This has even led some to compare these conflicts to America's troubled involvement in Vietnam in the 1960s and 1970s. But American foreign policy turned around fairly soon after the U.S. military withdrawal from Saigon in April 1975, an event that some are now connecting to Trump's decision to pull U.S. troops from their Syrian bases.

Yet by the early 1980s, the less-confident post-Vietnam America had given way to President Ronald Reagan's assertive and even confrontational approach to the Soviet Union and to new military action, such as the U.S. invasion of Grenada. In 1983, Soviet leaders sufficiently feared Reagan's newly energetic policies and worried that NATO's large-scale Able Archer military exercises might be a ruse to cover preparations for a major NATO attack on the U.S.S.R. Of course, 
Reagan's policies-and the domestic support behind them-were in part a reaction to Moscow's invasion of Afghanistan in 1979, a decision influenced in part by Soviet dreams of American retrenchment. The difference between the Cold War's zero-sum rivalry and today's is that the U.S. side of the ledger is much bigger than Russia's. Playing a weaker hand well can yield short-term successes, but it is not a sustainable national strategy for international leadership.

Russia probably has greater prospects as a "sovereignty provider" than a security provider, if one defines this narrowly to mean that Moscow's great power status, United Nations Security Council veto, and demonstrated willingness to oppose the United States can give other governments somewhat more flexibility in defying Washington by turning to Russia. Ultimately, however, one must wonder how many of its partners Russia can protect from the United States simultaneously with an economy one-tenth the size of America's and improving but still comparatively limited military capabilities. One must also wonder how many of Russia's prospective new partners actually want to gamble on a break with America rather than using visible conversations with the Kremlin to get a better deal from the White House.

Russia is visibly capable of exercising significant influence on carefully selected matters where conditions allow Moscow to make the most of its strengths, whether military, diplomatic, or economic. Whether Moscow can build a broader international role is less apparent; it will require more than filling in the spaces that the United States leaves blank. Doing so on a long-term basis will also require preparing for the next inevitable cycle of American activism. 